\title{
Self-determination, occupation and the authority to exploit natural resources - trajectories from four European judgments on Western
}

\section{Sahara}

\author{
Pål Wrange*
}

\section{Abstract}

In two recent cases before the Court of Justice of the European Union, the General Court (the first instance), a High Court in the UK (a referring instance) and the Grand Chamber of the Court found that a trade agreement and a fisheries agreement between Morocco and the EU cannot be applied to occupied Western Sahara without the consent of its people. In spite of the fact that it is the general view that Western Sahara is under belligerent occupation, none of the three courts invoked the law of occupation but instead based themselves on the principle of self-determination and the law governing the administration of non-self-governing territories, including the principle of permanent sovereignty over natural resources. A possible implication of these judgments is that that law and the law of occupation are converging in certain respects, in particular as regards long-term occupations. This pertains not only to the substantive rules on the exercise of authority, which seem to require that the

\footnotetext{
* Professor of International Law, Stockholm University; Director of the Stockholm Centre for International Law and Justice (SCILJ). Pal.wrange@juridicum.su.se. This text was presented in early draft form at the Minerva Center's (Hebrew University and Tel Aviv University) conference ' 50 Years after 1967: Evaluating the Past, Present and Future of the Law of Belligerent Occupation' in Tel Aviv on 23 May 2017. Material from the text was also presented at the panel discussion 'Analysing the Western Sahara Campaign Case' at Queen Mary on 3 May, 2018. I would like to thank the participants for valuable comments. I would also like to extend a warm thank you to the editors and reviewers at the Israel Law Review for extensive and very useful comments. For further comments: pal.wrange@juridicum.su.se.

Disclosure: I was confronted with the Western Sahara issue between 1996 and 2007 as a legal advisor at the Swedish Ministry for Foreign Affairs and since I resigned from the foreign service in 2010 I have frequently presented my views on that conflict, usually at the request of parties critical of the Moroccan regime in the territory. I have, however, never been affiliated with any of the stakeholders of the situation.
} 
people is heard, but also to the basis for the establishment of that authority, namely bare control.

\section{Introduction}

What rules apply to the use of natural resources in non-self-governing and in occupied territories, respectively, and is there really a difference between these regimes? These questions were the subject of two recent cases before the Court of Justice of the European Union (CJEU), which was confronted with the issue of the status of Western Sahara, the powers of Morocco over the territory (if any) and whether third parties (including the European Union [EU]) could enter into contracts with Morocco that apply to that territory. The cases concerned a web of bilateral agreements between the EU and Morocco [the EU Morocco Agreements] (see below, section 3). None of them specifies that Western Sahara is covered, but they had been applied as if it did.

In the first case, Frente Polisario (Polisario; the liberation front for the people of Western Sahara), asked the court to annul a liberalisation agreement on trade between the EU and Morocco in so far as it covered occupied Western Sahara. Partly echoing a legal opinion by former Legal Counsel of the UN, Hans Corell, the first instance of the CJEU (the General Court) annulled the agreement because the EU had not ascertained that 'the production of goods for export is not conducted to the detriment of the population of the territory concerned, or entails infringements of fundamental rights'. ${ }^{1}$ In the second case, a British High Court made a reference for a preliminary ruling to the CJEU. ${ }^{2}$ The UK court asked, inter alia, whether a Fisheries Partnership Agreement between the EU and Morocco is 'valid, having regard to ...

\footnotetext{
${ }^{1}$ Case T-512/12 Council of the European Union vs Front Populaire pour la liberation de la saguia-el hamra et du rio de oro (Front Polisario) [2016] OJ C068/33, para 228.

2 Western Sahara Campaign UK v Commissioners for Her Majesty's Revenue and Customs, Secretary of State for Environment, Food and Rural Affairs [2015] EWHC 2898 (QB) (Western Sahara). The reference mechanism enables national courts to question the Court of Justice on the interpretation or validity of European law.
} 
the extent to which the ... Agreement was concluded for the benefit of the Saharawi people [of Western Sahara], on their behalf, in accordance with their wishes and/or in consultation with their recognised representatives'.

The Court of Justice (the second and final instance) overturned the 2016 judgment of the General Court in the first case and rejected Polisario's application on the ground that the agreements did not cover Western Sahara. ${ }^{3}$ In the second judgment, from 2018, it ruled, on the same grounds, that the challenged fisheries agreement is not invalid. ${ }^{4}$ The Court found that Western Sahara is a non-self-governing territory which is not covered by Morocco's sovereignty and therefore does not fall under the treaties' designation 'Morocco'. Although the judgments explicitly dealt with obligations of third parties, like the EU, I will focus here on what they say about the obligations of administering and occupying states.

The law of belligerent occupation was born during the second half of the nineteenth century as a way to manage affairs between civilised nations in a jus publicum europeanum where military victory was becoming discredited as a sufficient justification for rule. ${ }^{5}$ The purpose of this regulation was to distinguish between occupation, as a termporary status, and conquest. ${ }^{6}$ The original recognised stakeholders of the law of occupation - as it came to be codified in the Hague

\footnotetext{
${ }^{3}$ As will be explained, both these judgments were in fact favourable for Polisario, since they confirmed that Western Sahara is not a part of Morocco and that Morocco cannot contract freely on Western Sahara's behalf.

${ }^{4}$ Case C-104/16 Council of the European Union vs Front Populaire pour la liberation de la saguia-el hamra et $d u$ rio de oro (Front Polisario) [2016] OJ C111/20 (Polisario 2016); Case C-266/16 Western Sahara Campaign UK $v$ Commissioners for Her Majesty's Revenue and Customs, Secretary of State for Environment, Food and Rural Affairs [2018] C260/39 (Polisario 2018).

${ }^{5}$ See Nehal Bhuta, 'The Antinomies of Transformative Occupation' (2005) 16 European Journal of International Law 721; Yutaka Arai-Takahashi, 'Preoccupied with Occupation: Critical Examinations of the Historical Development of the Law of Occupation' (2012) 94 International Review of the Red Cross 51, 56, 74-75 and passim. See also Eyal Benvenisti, The International Law of Occupation (2nd edn, Oxford University Press 2012) 41. cf also Lassa Oppenheim, 'Legal Relations Between an Occupying Power and the Inhabitants' (1917) 33 Law Quarterly Review 363, 363, '[t]he literature on the subject is to a great extent obscure, and the echo of the former rule that the occupant at once becomes the sovereign of the occupied territory resounds more or less distinctly in the writings of many publicists'.

${ }^{6}$ Arai-Takahashi (n 5) 56 and passim. See also Benvenisti (n 5) 21 ff.
} 
Regulations annexed to the Fourth Hague Convention of 1907 (Hague IV) ${ }^{7}$-- were the occupying power (OP) and the sovereign. Over time - and in particular after the adoption of the IV Geneva Convention in 1949 (GC IV) ${ }^{8}$-- the interests of the inhabitants of the occupied territory came to be acknowledged. However, it is important to note that those interests are the individual (though often parallel) interests of those inhabitants, not their collective, political interests. After the creation of the UN, the principle of self-determination has developed into a legal norm, challenging the title and right of colonial powers to their overseas acquisitions, often gotten through peaceful occupation of 'terra nullius'. According to some commentators, this principle has also come to suggested that the collective will of the occupied population should be given increasing importance (see below).

These questions on occupation and self-determination go to another, more basic question: what is the factual basis for the authority to rule over people and economic resources? If the traditional law of occupation suggested that it was the fact of effective control, invocations of the law of self-determination suggest that legitimate authority is based on another fact: the will of the people.

I will first present the Western Sahara issue from an international law perspective. Since the puprose of this article is not to analyse that situation per se, I will only give as much of a background as is necessary to understand the cases. Thereafter, I will present the two cases. Lastly, I will offer my reflections on what they might say about international law. The judgments by the CJEU, in particular the one from 2018, are significant also from an EU law perspective, but that is not the focus of this article.

\footnotetext{
${ }^{7}$ Hague Convention (IV) respecting the Laws and Customs of War on Land and its Annex: Regulations concerning the Laws and Customs of War on Land (entered into force 26 January 1910) Martens Nouveau Recueil (ser 3) 461 (Hague IV).

${ }^{8}$ Geneva Convention (IV) Relative to the Protection of Civilian Persons in Time of War (entered into force 21 October 1950) 75 UNTS 287 (GC IV).
} 


\section{International law and Western Sahara}

\section{1 Western Sahara}

In 1963, the Spanish colony of Western Sahara was listed as a non-self-governing territory by the United Nations. ${ }^{9}$ Three years later, the General Assembly urged Spain to organise a referendum on the territory's right to exercise its right to selfdetermination ${ }^{10}$, which Spain agreed to in 1974 but never carried out. In 1974, the UN General Assembly asked the International Court of Justice (ICJ) for an advisory opinion on the pre-colonial status of Western Sahara. ${ }^{11}$ The resolution had been supported by Morocco, which had hoped to find a basis for its claim to sovereignty. However, while the ICJ found that there had been pre-colonial ties between the territory of Western Sahara and Morocco, these ties were not 'of such a nature as might affect the application of ... the principle of self-determination through the free and genuine expression of the will of the peoples of the Territory' ${ }^{12}$ Hence, by implication, the Sahrawis had the right to form an independent state, if they so wished.

Shortly thereafter, on 6 November, King Hassan II of Morocco ordered the 'Green March' of civilians into Western Sahara, accompanied by military action. The same day, the UN Security Council, in Resolution 380, called upon Morocco to

\footnotetext{
9 There are a number of good recounts of this history. A recent, and very thorough one, is Ben Saul, 'The Status of Western Sahara as Occupied Territory under International Humanitarian Law and the Exploitation of Natural Resources' (2015) 27 Global Change, Peace and Security 301 which can serve as a default reference for this brief history; see in particular pp 305-307. See also Stephen Zunes, 'Western Sahara, Resources, and International Accountability' (2015) 27 Global Change, Peace \& Security 285; Jeffrey J. Smith, 'The Taking of the Sahara: the Role of Natural Resources in the Continuing Occupation of Western Sahara', (2015) 27 Global Change, Peace \& Security 263. Smith is a prolific writer on the Western Sahara issue. The cited issue of Global Change, Peace and Security (27(3)) was devoted to Western Sahara and natural resources. Another recent and good article, cited by the UK High Court (see below), is Martin Dawidowicz, 'Trading Fish or Human Rights in Western Sahara' in Duncan French (ed), Statehood and Self-Determination (Cambridge University Press 2013) 250.

${ }^{10}$ UNGA Res 2229(1966), 20 December 1966, UN Doc A/RES/2229 (1996).

${ }^{11}$ UNGA Res 3292(1974), 13 December 1974, UN Doc A/RES/3292 (1974).

12 Western Sahara, Advisory Opinion [1975] ICJ Rep 68, [162].
} 
'immediately to withdraw... all the participants in the march'. ${ }^{13}$ On 14 November, under military pressure, Spain agreed to cede administration of the territory to Morocco and Mauretania (which renounced its claims in 1979). On 26 February, Spain notified the UN Secretary-General that it was withdrawing and that it considered itself free from any responsibility for the territory. Morocco annexed Western Sahara in two steps in 1976 and 1979. Armed conflict ensued between Morocco and the Saharawi liberation front Polisario, and the latter became recognised by the UN as the legitimate international legal representative of the people of Western Sahara for the purpose of negotiations about the future of Western Sahara. ${ }^{14}$ In 1991, after UN led negotiations, a settlement plan - endorsed by the UN Security Council in Resolutions 658 and 690 - was signed. ${ }^{15}$ Under that plan, a referendum on independence was to be held. Mostly due to lack of cooperation by Morocco (according to most observers) ${ }^{16}$, the plan was never implemented, and a few years later Morocco declared that independence for Western Sahara was no longer an option. ${ }^{17}$ A very fledgling peace process between Morocco and Polisario is still going on under UN aegis, for the purpose of achieving 'a just, lasting, and mutually acceptable political solution, which will provide for the self-determination of the people of Western Sahara'. ${ }^{18}$

No state has recognised Moroccan sovereignty over Western Sahara, but nonrecognition has been lesss consistent than in some other comparable conflicts, like the Middle East or Crimea. ${ }^{19}$ Under the name the Sahrawi Arab Democratic Republic

\footnotetext{
13 UNSC Res 380(1975), 6 November 1975, UN Doc S/RES/380 (1975).

14 UNGA Res 34/37(1979), 21 November 1979, UN Doc A/RES/34/37 (1979).

${ }_{15}$ UNSC Res 658(1990), 27 June 1990, UN Doc S/RES/358 (1990); UNSC Res 690(1991), 29 April 1991, UN Doc S/RES/690 (1991).

${ }^{16}$ Karima Benabdallah, 'The Position of the European Union on the Western Sahara Conflict' (2009) 17 Journal of Contemporary European Studies 417, 420.

17 Zunes (n 9) 297.

18 This is standard language of the Security Council quoted from UNSC Res 2414 (2018), on 27 April 2018, UN Doc S/RES/2414 (2018), preambular paragraph 4. See further Report of the Secretary-General on the situation concerning Western Sahara, 29 March 2018, UN Doc S/2018/277 (2018), paras 17-31, 77-90.

19 See Pål Wrange and Sarah Helaoui, 'Occupation/Annexation of a Territory: Respect for
} 
(SADR) (linked to Polisario), Western Sahara is a member of the African Union. A very large part of the Sahrawi population has fled to refugee camps in Algeria, while Moroccan settlers have moved in, investors have been allotted land, concessions have been granted and new infrastructure has been built for the needs of the newcomers and their exploitation of phosphates, fish and other natural resources. ${ }^{20}$

\subsection{International law: occupation, annexation, non-self-governing}

As mentioned, Western Sahara is included in the UN's list of non-self-governing territories. ${ }^{21}$ For such territories, the principle of self-determination and the law relating to non-self-governing territories (NSGTs) apply. Under modern international law, it is a violation of the principle of self-determination to keep such territories under colonial or 'alien' control.22 Common Article 1 of the two 1966 UN human rights covenants provides that '[a]ll peoples have the right of selfdetermination' including to 'freely determine their political status and freely pursue their economic, social and cultural development.' The Friendly Relations Declaration reiterates this and adds that '[t]he territory of a colony or other Non-Self-Governing Territory has, under the Charter, a status separate and distinct from the territory of the state administering $\mathrm{it}^{\prime 23}$. Hence, such a territory is not a part of the state that administers it. ${ }^{24}$

A colonial power is generally referred to as 'administering power' (AP) and an administering power has the responsibility to assist the people in the colony to reach

\footnotetext{
International Humanitarian Law and Human Rights and Consistent EU Policy', Report for the European Parliament, 25 June 2015,

http://www.europarl.europa.eu/thinktank/en/document.html?reference=EXPO STU(2015)534995.

${ }^{20}$ See further, Karen Arts and Pedro Leite (eds), International Law and the Question of Western Sahara (International Platform of Jurists for East Timor 2007).

${ }^{21}$ For the latest annual report see, Report of the Special Committee on the Situation with regard to the Implementation of the Declaration on the Granting of Independence to Colonial Countries and Peoples for 2017, 11 July 2017, UN Doc A/72/23 (2017).

22 UNGA Res 2625(XXV)24 October 1970, UN Doc A/RES/2625 (1970).

23 ibid.

${ }^{24}$ On the term 'people', see briefly $\mathrm{n} 70$.
} 
full self-determination, which usually means independence. ${ }^{25}$ It is slightly controversial if Spain is still the de jure AP over Western Sahara (although I think so), ${ }^{26}$ but for the purpose of this discussion, it is not necessary to determine that issue. What is relevant here is that Morocco has not claimed to have taken over that role, and it has not been recognised by any one to have done so.

It is clear that Western Sahara was occupied in 1975 against the will of the AP, Spain, ${ }^{27}$ and certainly against the will of the people concerned. ${ }^{28}$ The Madrid agreement of 14 November 1975 did not change that, because it was concluded under military coercion and because Spain did not have the right to cede the territory to another state but was under an obligation to ensure the selfdetermination of the people of that territory. ${ }^{29}$ The Friendly Relations Declaration declares that ' $[t]$ he territory of a State shall not be the object of acquisition by another State resulting from the threat or use of force' and '[n]o territorial acquisition resulting from the threat or use of force shall be recognized as legal' ${ }^{30}$ An illegally

\footnotetext{
${ }^{25}$ Article 76 of the UN Charter also mentions self-government as an option, but in practice the goal has generally been independence.

${ }^{26}$ The UN list of non-self-governing territories does not indicate an administering power for Western Sahara but notes the following 'On 26 February 1976, Spain informed the Secretary-General that as of that date it had terminated its presence in the Territory of the Sahara and deemed it necessary to place on record that Spain considered itself thenceforth exempt from any responsibility of any international nature in connection with the administration of the Territory, in view of the cessation of its participation in the temporary administration established for the Territory. In 1990, the General Assembly reaffirmed that the question of Western Sahara was a question of decolonization which remained to be completed by the people of Western Sahara.' 'The United Nations and Decolonization: Non-Self-Governing Territories', http://www.un.org/en/decolonization/nonselfgovterritories.shtml. It is highly doubtful that Spain could avoid responsibility in this way.

${ }^{27}$ Saul (n 9) 315-16.

${ }^{28}$ Zunes (n 9) 288.

${ }^{29}$ Saul (n 9 309-15.
}

One could also make the argument that the conflict between Polisario and Morocco is an international conflict. Polisario is clearly a national liberation movement involved in a war of national liberation under Articler 1(4) of the First Additional Protocol to the Geneva Conventions. Morocco became a party to the protocol in 2011 and Polisario filed a declaration under Article 96(3) of the Protocol in 2015 , bringing the conventions and the protocol into immediate effect. Saul (n 9) 304. However, I strongly doubt that that can have a retroactive effects insofar as the initiation of a state of occupation is concerned. It is not necessary to settle that issue here, since the status of Western Sahara as a occupied territory is clear to my mind.

30 UNGA Res 2625(XXV) (n 22). 
annexed territory is, for the purpose of international law, still occupied. ${ }^{31}$ The status of Western Sahara is therefore that of occupied territory, as concluded by the UN General Assembly, which in 1979 and 1980 urged Morocco to terminate the occupation. ${ }^{32}$ It is therefore logical that the prevailing view among international lawyers is that Western Sahara is not a part of Morocco and that the annexation was without effect, and most also find the territory to be occupied. ${ }^{33}$

International humanitarian law (IHL) limits the authority of an occupying power and balances between the interests of the occupying power, the ousted sovereign and the civilian population. Occupation is supposed to be a temporary affair. ${ }^{34}$ Article 43 of the IV Hague Convention of 1907 provides that 'the occupant ... shall ... unless absolutely prevented, [respect] the laws in force in the country' ${ }^{35}$ This conservationist preference was modified a bit in 1949, through article 64 (3) of GC IV. Hence, an OP shall, as a maïn rule, respect the laws of the occupied territory, subject to exceptions necessary for the security of the occupant and for public order and civil life, as well as measures necessary to respect other provisions of IHL and human rights (see below). ${ }^{36}$ For all types of status - occupation, annexation, non-selfgoverning - human rights apply (as always), ${ }^{37}$ even though the precise relation

\footnotetext{
${ }^{31}$ See art 47 of GC IV.

32 UNGA Res 34/37 (n 14) and UNGA Res 35/19(1980), 11 November 1980, UN Doc A/RES/35/19 (1980).

${ }^{33}$ Neither the fact that Spain stopped resisting the armed activities of Morocco nor the fact that the territory is claimed by no other state than Morocco prevents that conclusion. See Advocate General's Opinion in Case C-266/16 Western Sahara Campaign v Secretary of State for Environment, Food and Rural Affairs and Commissioners for Her Majesty's Revenue and Customs [2018], p 67 and the magnificent footnote 223 (Advocate General, 2018).

34 The First Additional Protocol does not contain an end date but the application of some of the provisions of the GC IV ends after one year according to art 6, GC IV (n 8).

${ }^{35}$ Hague IV (n 7). The convention was drafted in French, which is the only official language of the convention. The most common English translation uses the expression 'public order and safety', which is a quite poor translation of 'l'ordre et la vie publics'. I subscribe to the expression 'public order and civil life', which is the expression used by Benvenisti (n 5).

${ }^{36}$ The debate on so-called transformative occupation, prompted by the US-led coalition's occupation of Iraq, has been intense, but will not be visited here. Suffice it to say that there is overwhelming scholarly support for the position that the old rules remain.

${ }^{37}$ Legal Consequences of the Construction of a Wall in the Occupied Palestinian Territory, Advisory Opinion [2004] ICJ Rep 136 [106] (Wall).
} 
between human rights law and the law of occupation is not settled..$^{38}$

A particularly debated question for both non-self-governing and occupied territories is the use of natural resources. Under the law of self-determination, a people has a right to permanent sovereignty over its natural resources and the right to 'freely dispose of their natural wealth and resources', as provided in Article 1(2) of the two UN covenants on human rights. The rules governing the administration of non-selfgoverning territories, including Article 73 of the UN Charter, point in the same direction. This was developed in 2002 in a legal opinion by the then UN Legal Counsel, Hans Corell. ${ }^{39}$ The opinion, which will be discussed below, concluded, with regard to oil exploration in the waters outside Western Sahara, that if 'activities were to proceed in disregard of the interests and wishes of the people of the occupied territory, they would be in violation of the international law principles applicable to mineral resource activities in Non-Self-Governing Territories' ${ }^{40}$

Under the law of occupation, an OP cannot use natural resources arbitrarily for its

\footnotetext{
${ }^{38}$ In the authoritative - but not unchallenged - view of the International Court of Justice, IHL is lex specialis, meaning that IHL trumps human rights in cases of conflict. Legality of the Threat or Use of Nuclear Weapons, Advisory Opinion [1996] ICJ Rep 226 [25]-[26]. See also Yiram Dinstein, The International Law of Belligerent Occupation (Cambrdge University Press 2009) 85-86. However, it is also possible to see them as complementary. Yutaka Arai-Takahashi, The Law of Occupation: Continuity and Change of International Humanitarian Law, and its Interaction with International Human Rights Law (Martinus Nijhoff Publishers 2009) 419-22 (Arai-Takahashi, The Law of Occupation).

Some states - like the US and Israel - do not agree that human rights apply outside a state's territory. See generally, Arai-Takahashi, The Law of Occupation, 551-82. While the scope of application differs between different conventions, the established majority view - including by the International Court of Justice (ICJ - is that human rights in principle do apply globally. Wall (n 37) [108-13]. This is also the view adopted by the European Court of Human Rights, ECtHR, Al-Skeini v United Kingdom, App No. 55721/07, 7 July 2011. For my own view, see Pål Wrange, 'Intervention in National and Private Cyber Space and International Law', in Jonas Ebbesson and others (eds), International Law and Changing Perceptions of Security: Liber Amicorum Said Mahmoudi' (Brill-Nijhoff 2014) 307, 324-25.

${ }^{39}$ Hans Corell, Letter dated 29 January 2002 from the Under-Secretary-General for Legal Affairs, the Legal Counsel, addressed to the President of the Security Council, 29 January 2002, UN Doc S/2002/161 (2002).

${ }^{40}$ My emphasis. It should also be noted that since 1995, the General Assembly has affirmed 'the value of foreign economic investment undertaken in collaboration with the peoples of Non-Self-Governing Territories and in accordance with their wishes in order to make a valid contribution to the socioeconomic development of the Territories', UNGA Res 50/33(1995), 6 December 1995, UN Doc A/RES/50/33 (1995), para 2. That resolution has been reiterated annually.
} 
own purposes..$^{41}$ Nevertheless, it has the limited right of 'usufruct' to such resources under article 55 of the Hague Regulations.${ }^{42}$ Further, as mentioned, an OP has a responsibility to uphold public order and civil life and to care for the civilian population. ${ }^{43}$ This means that an OP must provide basic public goods to the population of OT, which entails that there must be income to pay for these goods. Consequently, the OP may use the resources of the occupied territory, but only if that benefits the people of that territory or covers other legitimate costs of the occupation. ${ }^{44}$

Hence, as will be discussed further below, there are similarities between the law on NSGTs and the law of occupation, in that the force in power cannot use natural resources for its own good and must consider the interests of the people under its command and possibly also their wishes.

So much for the applicable primary rules. However, since the four judgments concern the acts of third parties (the EU), their role must be considered briefly to set the background for the cases. In an illegal situation, third states have a number of

\footnotetext{
${ }^{41}$ As Crawford says, '[i]t is ... generally accepted that the occupier may not use the resources of the occupied territory for its own domestic purposes, but rather must use them "to the extent necessary for the current administration of the territory and to meet the essential needs of the population"'. James Crawford, 'Opinion: Third Party Obligations with respect to Israeli Settlements in the Occupied Palestinian Territories', 24 January 2012, 25 https://www.tuc.org.uk/sites/default/files/tucfiles/LegalOpinionIsraeliSettlements.pdf. The prohibition and criminalisation of pillage is also relevant; see Jean-Marie Henckaerts and Louise Doswald-Beck (eds), Customary International Humanitarian Law, Vol. I: Rules (International Committee of the Red Cross and Cambridge University Press 2005, revised 2009) 182-85. In the Armed Activities Case, the ICJ - controversially - found that the principle of permanent sovereignty over natural resources was not relevant to pillage. Armed Activities on the Territory of the Congo (Democratic Republic of the Congo v Uganda), Judgment [2005] ICJ Rep 168 [244].

${ }^{42}$ Dinstein (n 38) 213-18; See also the extensive discussion in Guy Harpaz and others, 'Expert Legal Opinion: HCJ 2164/09 Yesh Din - Volunteers for Human Rights $v$ Commander of IDF Forces in West Bank et al (December 26, 2011)', January 2012, https://s3-eu-west-1.amazonaws.com/files.yeshdin.org/\%D7\%A2\%D7\%AA\%D7\%99\%D7\%A8\%D7\%95\%D7\%AA/\%D7\%9E\%D7\%97\%D7\%A6\%D7\%9 1\%D7\%95\%D7\%AA/Quarries+Expert+Opinion+English.pdf This rule makes a distinction between exhaustible and non-exhaustible resources. It is controversial whether the occupying power may use exhaustible resources at all. At any rate, any use is subject to the conditions outlined in the body text. ${ }^{43}$ Art 43 Hague IV (n 7), as well as a number of provisions in the GC IV (n 8) indicate positive obligations for the occupying power, such as Articles 50, 55 and 56. ${ }^{44}$ See also Dinstein (n 38) 210.
} 
duties. ${ }^{45}$ They shall not recognise an illegal annexation and not assist in the continued occupation and annexation, and they should cooperate to bring an end to the illegal situation. ${ }^{46}$ It is therefore illegal to enter into an agreement with an occupying power, if that agreement explicitly or implicitly recognises the annexation of the occupied territory (OT) or if it otherwise assists in upholding an illegal situations. ${ }^{47}$ Nevertheless, it is not a given that a non-recognition should affect all decisions made by the relevant illegal authorities. In its seminal advisory opinion on Namibia, the ICJ stated that 'the non-recognition of South Africa's administration of the Territory should not result in the depriving the people of Namibia of any advantages derived from international co-operation' ${ }^{48} \mathrm{EU}-\mathrm{Morocco}$ relations

\footnotetext{
${ }^{45}$ See ICJ Wall (n 37) [159]. Although I believe that the opinion was right (in addition to being authoritative, it should be mentioned that it has been criticised). See also Article 41 of the Draft Articles on State Responsibility. International Law Commission, Responsibility of States for Internationally Wrongful Acts, annnexed to UNGA Res 56/83(2001), 12 December 2001, UN Doc
} A/RES/56/83 (2001).

${ }^{46}$ See in general, Stefan Talmon, "The Duty Not to "Recognize as Lawful" a Situation Created by the Illegal Use of Force or Other Serious Breaches of a Jus Cogens Obligation: An Obligation without Real Substance?' in Christian Tomuschat and Jean-Marc Thouvenin (eds), The Fundamental Rules of the International Legal Order: Jus Cogens and Obligations Erga Omnes (Martinus Nijhoff Publishers 2005) 99; David Turns, 'The Stimson Doctrine of Non-Recognition: Its Historical Genesis and Influence on Contemporary International Law' (2003) 2 Chinese Journal of International Law 105, 130-43.

${ }^{47}$ Talmon appears to be even more categorical. Talmon (n 46) 119; see also Tristan Ferraro, 'Expert Meeting: Occupation and other Forms of Administration of Foreign Territory', International Committee of the Red Cross, Expert Meeting Report, 11 June 2012, 59 (Expert Meeting).

${ }^{48}$ Legal Consequences for States of the Continued Presence of South Africa in Namibia (South-West Africa) notwithstanding Security Council Resolution 276, Advisory Opinion [1971] ICJ Rep 16 [125]. The Court went on to say '[i]n particular, while official acts performed by the Government of South Africa... after the termination of the Mandate are illegal and invalid, this invalidity cannot be extended to those acts, such as, for instance, the registration of births, deaths and marriages, the effects of which can be ignored only to the detriment of the inhabitants of the Territory'.

Cases in American and British courts suggest likewise, so as not to complicate the life of the current population as has case law in the European Court of Human Rights. See ECtHR, Cyprus $v$ Turkey App no 25781/94, 10 May 2001, paras 82-102. See further Enrico Milano, 'The Doctrine(s) of NonRecognition: Theoretical Underpinnings and Policy Implications in Dealing with De Facto Regimes' European Society of International Law, 2nd ESIL Research Forum Confrence Paper, 28-29 September 2007 ; Ralph Wilde, Andrew Cannon and Elizabeth Wilmshurst 'Recognition of States: the Consequences of Recognition or Non- Recognition in UK and International Law', Chatham House, Summary of the Internatonal Law Discussion Group Meeting, 4 February 2010; Stefan Talmon, 'The Cyprus Question Before the European Court of Justice' (2001) 12 European Journal of International Law 727.

GC IV (n 8) art 47, sets out the important principle that '[p]rotected persons who are in occupied territory shall not be deprived, in any case or in any manner whatsoever, of the benefits of the present 
The EU and Morocco have very close ties, which are based on an Association Agreement, in force since 2000. In 2008, Morocco became the first country in the southern Mediterranean region to be granted so-called 'advanced status', marking a new phase of 'privileged relations' ${ }^{49}$ In addition to the Association Agreement and an agreement on the liberalisation of trade in agriculture and fisheries products (2012; the liberalisation agreement), there is also a Fisheries Partnership Agreement (FPA). The FPA entered into force on 2007, but the implementing protocol to the FPA expired in February 2011. A new protocol was negotiated and adopted by a divided Council of Ministers in $2011^{50}$ but was rejected by the European Parliament, partly due to the controversy over the alleged reach of the agreement into Western Sahara. The European Commission then renegotiated the Protocol, which was adopted by the Council and Parliament in 2013. Unfortunately, the relevant changes in the protocol compared to 2011 were cosmetic, at best, and did not cure the problem related to the effect on Western Sahara (see below). ${ }^{51}$ While the FPA does not say so explicitly, it was meant to cover, and has indeed been applied to, the waters outside of Western Sahara, which provide the major part of the total fisheries allocated to the EU. ${ }^{52}$ The same seems to apply at least to some extent to the other economic agreements between the EU and Morocco. Furthermore, there is no indication that the agreements are for the benefit of the people of Western Sahara or

\footnotetext{
Convention by any change introduced [...] by any annexation'.

49 'European Neighbourhood Policy And Enlargement Negotiations: Morocco', European Commission, https://ec.europa.eu/neighbourhood-enlargement/neighbourhood/countries/morocco. The term 'advanced status' does not seem to have any independent legal significance, but is a political marker of approval. See Iván Martín, 'EU-Morocco Relations: How Advanced is the "Advanced Status"?', (2009) 14 Mediterranean Politics 239.

${ }^{50}$ The UK, Austria, Sweden, Finland, Denmark, Cyprus and the Netherlands voted against or abstained.

${ }^{51}$ See Pål Wrange and others, 'Western Sahara and the Protocol to the EU-Morocco Fisheries Partnership Agreement (FPA) of 2013 - a Legal Analysis', Memo, 2 December 2013, http://www.wsrw.org/files/dated/2013-12-05/western sahara fisheries legal analysis 2013.pdf. ${ }^{52}$ See 'Legal Opinion: RE. Fisheries Partnership Agreement between the European Community and the Kingdom of Morocco - Declaration by the Sharawi Arab Democratic Republic (SADR) of 21 January 2009 of jurisdiction over an Exclusive Economic Zone of 200 nautical miles off the Western Sahara - Catches taken by EU-flagged vessels fishing in the waters off the Western Sahara', 13 July 2009, para 29, http://www.wsrw.org/a105x1346.
} 
in accordance with their wishes, ${ }^{53}$ as will be discussed below. None of these documents mentions that Western Sahara is being occupied and illegally annexed. In fact, as stated above, the territory is not mentioned explicitly at all. ${ }^{54}$

\section{The Cases}

As indicated, the ever closer relations between the EU and Morocco are highly dubious in so far as they relate to Western Sahara. In this section, I will discuss how the four judgments in the two cases deal with international law questions relating to the use of natural resources. I will first present the two cases, the Polisario Case and the Western Sahara Campaign case, as they were dealt with by the General Court (the first instance of the CJEU) and the British High Court, respectively, and then present their treatment in the second instance, the Court of Justice. I will not summarise the views of the Advocate General (legal advisor) of the Court, but his views will be referred to later. Before that, however, it is necessary to discuss a legal opinion that played a great role in the proceedings.

\subsection{An opinion by the UN Legal Counsel}

As already mentioned, in 2002, the then legal counsel of the United Nations, Hans Corell, provided an opinion at the Security Council's request on the legality in the context of international law, including relevant resolutions of the Security Council and the General Assembly of the United Nations, and agreements

\footnotetext{
${ }^{53}$ See Wrange and Helaoui (n 19).

${ }^{54}$ In the, Council of the European Union, 'EU Annual Report on Human Rights and Democracy in the World in 2013', 23 June 2014, 198, it is stated, with a euphemism, that 'Western Sahara is a territory contested by Morocco and the Polisario Front' (emphasis added). That expression had disappeared, however, in the 2015 report. Council of the European Union, 'EU Annual Report on Human Rights and Democracy in the World in 2015 - Country and Regional Issues', 20 September 2016, 59. By some contrast, the US has made it clear, regarding their bilateral free trade agreement, that the designation 'Morocco' does not include Western Sahara. Letter of 20 July 2004 from the US Trade Representative, Robert Zoelleck, to Congressman Pitt. The letter is no longer available on the website of the US House of Representatives but can be retrieved here https://web.archive.org/web/20070906234744/http://www.house.gov/pitts/temporary/0407191-ustrmoroccoFTA.pdf.
} 
concerning Western Sahara of actions allegedly taken by the Moroccan authorities consisting in the offering and signing of contracts with foreign companies for the exploration of mineral resources in Western Sahara. ${ }^{55}$ Corell found that a response to the question required an analysis of both the status of Western Sahara in itself and the status of Morocco's relation to that territory. The opinion did not use words like 'occupation' but nevertheless noted that Spain had not, and could not, transfer sovereignty to Morocco and that Morocco was not listed as an administering power (para 6). This might suggest that Morocco has no title to administer the territory and is a mere occupant. Corell concluded, though

[n]otwithstanding the foregoing, and given the status of Western Sahara as a Non-Self-Governing Territory, it would be appropriate for purposes of the present analysis to have regard to the principles applicable to the powers and responsibilities of an administering Power in matters of mineral resource activities in such a Territory (para 8).

He found that Article 73 of the UN Charter applied and that resource exploitation in Non-Self-Governing Territories that is 'for the benefit of the peoples of those territories, on their behalf, or in consultation with their representatives' is in line with the relevant obligations and the principle of permanent sovereignty over natural resources (para 24). Hence, any exploration must be in line with 'the interests and wishes of the people of Western Sahara' (para 25). ${ }^{56}$ This opinion has been referred to frequently by parties, on both sides of the argument, regarding all forms of economic relations with Morocco over Western Sahara. Corell himself has interpreted this requirement to apply also to fishing and to be taken as a restriction

\footnotetext{
${ }^{55}$ Hans Corell, Legal Counsel Letter (n 39) para 1.

${ }^{56}$ A terminological note: In most discourse on occupation, the collective of individuals living under occupation is referred to as a 'population'. In some situations, where there is a considerable number of colonial settlers from the occupying power, it is necessary to make a distinction between the people and the population. See further $n 70$.
} 
rather as a than a license..$^{57}$ will refer to this opinion both in the reviews of the proceedings and in the succeeding discussion

\subsection{The Polisario Case in the General Court}

In December 2012, Polisario asked the CJEU to annul the EU Council's decision of the same year to adopt the liberalisation agreement on trade in agricultural and fishery products in so far as it covered Western Sahara. ${ }^{58}$

As a preliminary matter, the Court had to deal with the question whether Polisario had standing. ${ }^{59}$ Here the court held 'that the applicant is one of the parties to a dispute concerning the fate of that non-self-governing territory' (para 57) and, as such, 'may be directly and individually concerned by the contested act' (para 73). Hence, the standing of Polisario hinged on whether the agreement does apply to Western Sahara or not (para 72). Polisario held that Morocco 'does not administer Western Sahara under Article 73 of the United Nations Charter, but occupies it militarily' (para 76). The Court did not settle the question whether Western Sahara was occupied or not. However, it did find that the agreement applied also to Western Sahara (para 103); the framework association agreement had in fact been applied to that territory, and there was no explicit exception clause. Consequently, there was 'no doubt as to the admissibility of [Polisario's] action', since it was affected by the agreement (para 114). As we will see below (in 4.4), the second instance drew a different conclusion in that regard.

Moving on to the substance, the General Court found that the application essentially concerned two questions. First: whether it is categorically prohibited for the EU to conclude an international agreement 'which may be applied to a territory in fact

\footnotetext{
${ }^{57}$ Hans Corell, 'The Legality of Exploring and Exploiting Natural Resources in Western Sahara', Western Sahara Conference Proceedings, 5 December 2008, http://www.havc.se/res/SelectedMaterial/20081205pretoriawesternsahara1.pdf.

58 Polisario, 2015 (n 1). See also n 3.

${ }^{59}$ Before that, the court found that Polisario must be regarded as a 'legal person' within the meaning of relevant EU law and therefore had such capacity. ibid para 60.
} 
controlled by a non-member State', even though the sovereignty of that State over that territory has not been recognised by the EU and its Member States. Second: If there is no such categorical prohibition, and the EU institutions therefore have discretion in that regard, have they respected 'the limits of that discretion and the conditions for its exercise' (para 117).

The court found that the application of the agreement to Western Sahara does not amount to recognition of sovereignty over that territory (para 202), and that it is not absolutely prohibited to conclude agreements which relate to such territories (para 215). Consequently, the sticking point was how the Council's had exercised its discretion (para 225). The Court related - without questioning -- the aforementioned finding by Corell that 'resource exploitation activities [must be] conducted in Non-Self-Governing Territories for the benefit of the peoples of those Territories, on their behalf or in consultation with their representatives' (paras 208, 222, 229). It then noted that Morocco does not have any mandate from the UN or another international body to administer the territory, and its failure to comply with the reporting obligation under Article 73(e) of the UN Charter 'is, at the very least, likely to give rise to doubt as to whether [it] recognises the principle of the primacy of the interests of the inhabitants of that territory and the obligation to promote to the utmost their wellbeing' (paras 233, 235 respectively). Further, the Court noted that it is clear that Morocco considers 'Western Sahara to be part of its territory' (para 235).

Accordingly, if it were the case that the Kingdom of Morocco was exploiting the resources of Western Sahara to the detriment of its inhabitants, that exploitation could be indirectly encouraged by the conclusion of the agreement approved by the contested decision (para 238).

Hence, while it was not clear whether the Court held that Morocco was an administering power or not, the Court clearly found that Morocco had to comply with the obligations incumbent upon such a power, and that it had not done so. 
Therefore, in the exercise of its discretion, the Council

'should have satisfied itself that there was no evidence of an

exploitation of the natural resources of the territory of Western Sahara

under Moroccan control likely to be to the detriment of its inhabitants

and to infringe their fundamental rights (para 241).

Since the Council had failed in that respect, the Court annulled the decision 'in so far as it approves the application of that agreement to Western Sahara' (para 247).

The judgment was appealed by the Council, which was supported by the Commission (intervener) and a number of states (see section 4.4).

\subsection{The Western Sahara Campaign Case in the British High Court}

In the British case, ${ }^{60}$ the claimants, Western Sahara Campaign UK, contended that the defendant -- the Secretary of State for Environment, Food and Rural Affairs - is acting unlawfully by applying the Fisheries Partnership Agreement to Western Sahara. ${ }^{61}$ The judge, Justice Blake, found that it was clear that fishing, licensed under the agreement, had taken place 'within the territorial waters of the Western Sahara' (paras 28-29). Thus, in order to determine whether the UK authorities in question had acted unlawfully, it was necessary to first determine what the agreements actually meant. Since they had been concluded by the EU, Justice Blake needed to get a so-called preliminary ruling from the CJEU about the agreements and asked inter alia the following question to the CJEU

Is the Fisheries Partnership Agreement between the EU and the Kingdom of

\footnotetext{
60 Western Sahara (n 2).

${ }^{61}$ The British Case also involved a claim against the Commissioners for Her Majesty's Revenu and Customs regarding the application of the liberalisation agreement. The original reference from 2016 covered also that agreement, but those questions were withdrawn, since they had been answered in the Polisario judgment from 2016. In order to simplify the already complex review, I decided to omit any references to that part of the case. Further, there was a fourth question concerning the standing of Polisario, which is less relevant for the current discussion.
} 
Morocco $^{62} \ldots$ valid, [having regard to the requirement under Article 3(5) of the Treaty on European Union to contribute to the observance of any relevant principle of international law and respect for the principles of the United Nations Charter .... $]^{\prime}$

Justice Blake found that Morocco's presence constitutes 'belligerent occupation' ${ }^{63}$ He noted that the UN recognises 'that Morocco de facto administers the territory but neither the UN, the OAU [Organization of African Unity], the Member States of the EU, nor the Union itself recognise that Morocco has a de jure claim to sovereignty or rights of occupation' (para 18). Justice Blake then reviewed Morocco's claim to the territory and dismissed all possible bases. 'A colonial power cannot gift an occupied territory to a neighbouring state ... Equally, unauthorised military occupation cannot found the basis for legitimate territorial claims' (para 40). He concluded that the sovereign territory of Morocco does not include Western Sahara (para 40). Before moving on in the argument, one should note - as will be discussed below in section 5 - that Blake did not discuss whether the law of occupation should apply; the only hint in this respect is his taking note of the fact that no 'rights of occupation'(para 18) had been recognised. Instead, it was the law on NSGT's that seemed to guide the judgment.

The next step in the reasoning was Justice Blake's query what is 'legitimate for a body respecting the principles of the UN Charter' (para 40). He found that 'it would not be a manifest error' for the Commission to hold that it could enter into an

\footnotetext{
${ }^{62}$ As approved and implemented by Council Regulation (EC) 764/2006 of 22 May 2006 on the conclusion of the Fisheries Partnership Agreement between the European Community and the Kingdom of Morocco [2006] OJ L141/1 (2), Council Decision (EU) 2013/785 of December 2013 on the conclusion, on behalf of the Europian Union, of the Protocol between the European Union and the Kingdom of Morocco setting out the fishing opportunities and financial contribution provided for in the Fisheries Partnership Agreement between the European Union and the Kingdom of Morocco [2013] OJ L349/1 (3), and Council Regulation (EU) 1270/2013 of 15 November 2013 on the allocation of fishing opportunities under the Protocol between European Union and the Kingdom of Morocco setting out the fishing opportunities and financial contribution provided in the Fisheries Partnership Agreement between the European Union and the Kingdom of Morocco [2013] OJ L238/40 (4). ${ }^{63} \mathrm{He}$ here referred to the article by Dawidowicz (n 9).
} 
agreement for the exploitation of natural resources, in spite of the 'continued occupation of the territory of the Western Sahara' (para 43). However, Blake found that some conditions would have to be fulfilled for such agreements to be made (para 47)

It may be that the benefits need to be directed specifically to the indigenous population. If this cannot be achieved as a matter of political practicality then no agreement should be entered with an administering power that:

i) does not recognise that this is its status and

ii) does not act in accordance with all the obligations imposed by Article 73 of the Charter,

iii) and in particular does not acknowledge the obligation to promote the selfdetermination of the people of Western Sahara.

Justice Blake then referred to Articles 40 and 41 of the International Law Commission's Draft Articles on State Responsibility which provide that states have a duty to cooperate to end serious breaches of customary international law (para 49). He also quoted a paper by Corell from 2008 (paras 51-53), in which the 2002 opinion is applied to the Fisheries Partnership Agreement: ${ }^{64}$

I find it incomprehensible that the Com mission could find any such support in the legal opinion, unless, of course, it had established that the people of Western Sahara had been consulted, had accepted the agreement, and the manner in which the profits from the activity were to benefit them.

The conclusion was 'that there is an arguable case of a manifest error by the Commission in understanding and applying international law relevant to these agreements' (para 55).

${ }^{64}$ Corell (n 57) 242. 


\subsection{The Polisario Case and the Western Sahara Campaign Case in the Grand Chamber of the Court of Justice}

The Grand Chamber of the CJEU dealt with the two cases in 2016 and 2018, respectively, with essentially the same line of reasoning. ${ }^{65}$ In 2016, it dismissed Polisario's claim, not for substantive reasons but because the claimant lacked standing; Polisario was not affected by the agreements since they did not cover Western Sahara, in the Court's reading. In 2018, it found that the FPA was not invalid, since it, too, did not cover Western Sahara.

The court based these conclusions on a line of reasoning around the rules in the Vienna Convention on the Law of Treaties, ${ }^{66}$ including Article 31 on the interpretation of treaties (paras 81, 86, 94, 100, 2016). It first set out to interpret the words 'territory of the Kingdom of Morocco' in Article 94 of the Association Agreement, on which the challenged liberalisation agreement was based (para 92, 2016). Referring to the rule in Article 29 of the Vienna Convention, ${ }^{67}$ the Court found that a treaty is generally binding on a State in the ordinary meaning to be given to the term territory' ... in respect of the geographical space over which that State exercises the fullness of the powers granted to sovereign entities by international law (para 95, 2016).

Having said that, the Court found that the words 'territory of the Kingdom of Morocco' could not be interpreted to mean that Western Sahara was included within the territorial scope of that agreement (para 97, 2016; para 64, 2018). This finding was inter alia based on a review of the customary principle of self-determination, which is 'a legally enforceable right erga omnes and one of the essential principles of

\footnotetext{
${ }^{65}$ See $\mathrm{n} 4$.

${ }^{66}$ Even if that treaty is not binding on all members of the EU (France is a famous non-party), the relevant rules express customary international law, in the view of the Court. The court therefore uses terms like 'the rule expressed in article $X^{\prime}$ '.

${ }^{67}$ Vienna Convention on the Laws of Treaties (entered into force 27 January 1980) 1155 UNTS 331 (VCLT) Art 29, 'Unless a different intention appears from the treaty or is otherwise established, a treaty is binding upon each party in respect of its entire territory'.
} 
international law' (para 88, 2016). In particular, with reference to the Friendly Relations Declaration, 'the territory of a colony or other Non- Self-Governing Territory has, under the [UN] Charter, a ... separate and distinct [status]' (para 90, 2016). Hence, while the Court did not state that Western Sahara was under occupation, its finding that this territory was not a part of Morocco but had a separate status must mean that the Court treated the annexation as null and void. ${ }^{68}$ However, the Court also noted that 'a treaty may, by way of derogation from the general rule ... bind a State in respect of another territory if such an intention is apparent from that treaty or is otherwise established' (para 98). In the subsequent inquiry into the 'intentions' of the parties the Court felt that it needed to determine the state of the law, in order to ascertain what could possibly have been their intentions, and in particular the intentions of the EU. With reference to the ICJ's Advisory Opinion on Western Sahara and General Assembly Resolution 34/37, ${ }^{69}$ the Court found that the people of Western Sahara was a third party to the agreement, and as such, they had not consented to be affected by it. By reference to Article 34 of the Vienna Convention (paras 100,106, 2016), the Court concluded that ' $\mathrm{i}] \mathrm{n}$ those circumstances, it is contrary to the principle of international law of the relative effect of treaties to take the view that the territory of Western Sahara comes within the scope of the Association Agreement' (para 107, 2016). ${ }^{70}$

The Court then discussed the fact that the system of tariff preferences in the trade agreement had been 'applied "de facto" to products originating in Western Sahara' (para 118, 2016). However, if this subsequent practice had reflected the intention that

\footnotetext{
${ }^{68}$ The Advocate General of the Court had even suggested that Spain is still the administering power. Opinion of the Advocate General, Case C-104/16 Council v Front Polisario [2016], p 22 (Advocate General, 2016).

${ }^{69}$ UNGA Res 34/37 (n 14).

${ }^{70}$ There is an important distinction between people and population. A 'people' is a political unit, with a right of self-determination. It is thus distinct from a population or 'the inhabitants of a territory'. A population is a group of people who happen to live at the same place. It may consist of a people in the legal sense, but it may also consist of colonialists and settlers. This nomenclature was of some relevance to the cases, but I omitted that discussion.
} 
the agreements be applicable to Western Sahara, that would mean 'that the European Union intended to implement those agreements in a manner incompatible with the principles of self-determination and of the relative effect of treaties ' (para 123, 2016). ${ }^{71}$ That would 'necessarily be incompatible with the principle that Treaty obligations must be performed in good faith' (para 124, 2016). Therefore, there could be no such intention. With a similar line of reasoning, the court dismissed the argument that prior or subsequent practice regarding the FPA would change the geographical scope of that agreement (paras 80-83, 2018).

In 2018, the Court also considered the possibility that Morocco might be a 'de facto administrative power' or an occupying power. The CJ did not bother to determine whether that would have been 'compatible with the rules of international law' because there could have been no such common intention, 'since the Kingdom of Morocco has categorically denied that it is an occupying power or an administrative power' (para 72, 2018).

Hence, the Court of Justice concluded in 2016 and 2018 that none of the agreements covered Western Sahara, and therefore, none of them should be invalidated. Consequently, Polisario is a third party, not affected by the treaty, and has no standing to seek annulment of the decision. Hence, Polisario's action was dismissed (paras 131-134, 2016) (although its reasoning in fact brought a victory to the claimants) and the British High Court's question was answered positively.

To summarise, Both instances of the CJEU held that the presumption must be that an agreement does not apply beyond the recognised border of a state and that Western Sahara is not a part of Morocco, and the High Court reached a similar conclusion. Further, the three courts held that it may nevertheless be possible for two parties to conclude an agreement that covers their actions on such territory, but only under

\footnotetext{
${ }^{71}$ The Advocate General was even more explicit: ' $[\mathrm{I}] \mathrm{t}$ is settled case-law that the Union must respect international law in the exercise of its powers..." all States are under an obligation not to recognise"' or '"render aid or assistance in maintaining the situation created by"' an infringement of a jus cogens norm, including the right to self-determination. Advocate General, 2016 (n 68),paras 256-58.
} 
certain conditions. In this case, those conditions were not fulfilled, and therefore, such an agreement could not be allowed. The General Court found that it (the agreement) had nevertheless happened (and therefore should be anulled), while the Court of Justice - perhaps tongue in cheek - asserted that since that would be unthinkable, it could not have happened. The CJ did not state the precise conditions for a legally sound agreement other than that the principle of self-determination has to be satisfied (para 123, 2016) including the 'consent of such a third party' (para 106, 2016). However, both the General Court in the first case and the British High Court referred quite extensively to the legal opinion from 2002 by the UN Legal Counsel, and so did the Advocate General in the two cases.

\section{Implications}

The outcomes of the four judicial proceedings were politically favourable for Polisario, since they confirmed that Western Sahara is not a part of Morocco and that Morocco cannot contract freely on Western Sahara's behalf. What concerns us here, however, are the implications for the law. While it is certainly possible to argue for a position differing from that of these legal institutions, I find it more interesting to take them at face value. In distinction to the de lege lata discussion in subsection 2.2, this one is conjectural and speculative, almost a thought experiment - could one fuse the two regimes?

\subsection{The relation between the two regimes}

To briefly recount the review of the law in subsection 2.2 , both the law on NSGTs and the law of occupation provide that the force in power cannot use natural resources for its own good and must consider the interests of the people concerned and possibly also their wishes. However, the two regimes are distinct and built on different legal sources, and these sources do not state how substantive differences between the two should be dealt with in situations where both may be applied. How did the four legal institutions (the UN Legal Counsel, the High Court and the 
two instances of the CJEU) think of the relation between the regimes? The claimants in the four proceedings explicitly assumed that Western Sahara was occupied and the High Court (as well as the Advocate General ${ }^{72}$ ) clearly agreed. While neither of the two instances of the CJEU used the term occupation, they both held that Western Sahara was not a part of Morocco and, as developed above, that strongly suggests that Western Sahara is occupied. Hence, the courts could have applied the law of occupation, which has a treaty based and fairly detailed regime that includes highly relevant rules on the right of usufruct and a prohibition of colonial settlements but no explicit obligation to consult the population concerned..$^{73}$

Nevertheless, neither the UN Legal Counsel nor the three courts discussed the law of occupation. The Court of Justice clearly saw no need for that, since it did not consider the treaties to be applicable to Western Sahara. ${ }^{74}$ However, the opinions of the other three legal institutions suggest interesting conclusions about the relation between the law of occupation and the law on NSGTs. Since the UN legal counsel, the UK High Court and the General Court did not apply the law of occupation, they must have thought either that NSGT law trumps the law of occupation, ${ }^{75}$ probably as lex specialis, or that the two regimes say essentially the same thing. ${ }^{76}$ If any of these

\footnotetext{
72 Advocate General, 2018 (n 33) paras 245-250.

${ }^{73}$ See the Advocate General's invocation of Article 49 of the IV Geneva Convention, Advocate General, 2018 (n 33) para 283. Neither the Hague Conventions nor the Geneva Conventions and their additional protocols mention any such obligation, and nor does the ICRC list of rules under customary IHL. Jean-Marie Henckaerts, 'Study on Customary International Humanitarian Law: A Contribution to the Understanding and Respect for the Rule of Law in Armed Conflict' (2005) 87 International Review of the Red Cross 175, 198-212.

${ }^{74}$ However, if new treaties, covering Western Sahara, would be negotiated, the CJEU would have to pronounce itself on that issue. The Commission has received mandates to renegotiate all the relevant agreements.

${ }^{75}$ There were certainly arguments available for that position; there are fairly well-established rules developed for the governance of the natural resources of an NSGT, and, further, the courts could have held that a non-self-governing people is in such a vulnerable position that the more benign rule should apply, anyway. Please note that I find that in this instance, the law relating to non-selfgoverning territories is more advantageous for the people of Western Sahara. For a useful discussion of the relation between the law of occupation and the law relating to non-self-governing territories, see Eugene Kontorovich, 'Economic Dealings with Occupied Territories' (2015) 53 Columbia Journal of Transnational Law 584, 610-15.

${ }^{76} \mathrm{It}$ is possible that the High Court thought that the belligerent rights of an occupying force can be
} 
two applies, it is unnecessary to refer to the law of occupation or to even determine whether it applies. ${ }^{77}$ Therefore, it seems that these three bodies thought either that the two regimes are very similar or that the NSGT regime prevails.

Hans Corell confirmed this in a circumscribed way in 2008, when he recalled, in his private capacity, that in the deliberations before the 2002 opinion, the law of occupation was considered, but that he had found the best way forward was to 'make an analysis by analogy' to the law applicable to NSGTs. 'Any limitation of the powers of such an entity acting in good faith, would certainly apply a fortiori to an entity that did not qualify as an administering power but de facto administered the territory. ${ }^{78}$ This more than suggests at least that the law of occupation - even if applicable -- could not have changed the application of NSGT rules. The Advocate General was more explicit about the relation between the two regimes, and found that they 'are not mutually exclusive'. Further, he stated, there is a point of convergence between Article 55 of the 1907 Hague Regulations and the principle of permanent sovereignty over natural resources, "namely that the exploitation of the natural resources of Western Sahara ... must be carried out for the benefit of the people of Western Sahara'. ${ }^{79}$ Since I find it difficult to argue that the NSGT regime in general trumps the law of occupation (which is an extraordinary regime, a lex specialis), I will proceed from the assumption that the two regimes are similar or at least blend easily. ${ }^{80}$

exercised only if they have been recognised or have some other sound legal basis, but if so, that opinion was just alluded to, not developed. Western Sahara (n 2) para 18.

77 While the High Court explicitly stated that Western Sahara was occupied, neither the UN legal counsel nor the General Court could have dismissed the law of occupation without analysis, had it been relevant.

${ }^{78}$ Corell (n 57) 238.

${ }^{79}$ Advocate General, 2018 (n 68) 53. '[T] he legal regimes applicable to non-self-governing territories and to occupied territories are not mutually exclusive'.

${ }^{80}$ See Phoebe N. Okowa, 'Natural Resources in Situations of Armed Conflict: Is there a Coherent Framework for Protection?' (2007) 9 International Community Law Review 237. See also Sandra Hummelbrunner and Anne-Carlijn Pickartz, 'It's not the Fish that Stinks! EU Trade Relations with Morocco under the Scrutiny of the General Court of the European Union' (2016) 32 Utrecht Journal of International and European Law 19, 29; Marco Longobardo, 'State Responsibility for International 


\subsection{Merger or mixing of the two regimes?}

As mentioned in subsection 2.2, the occupation law of the 1907 Hague Regulations (Hague IV) emphasised the rights of the ousted government, while the Fourth Geneva Convention made the occupied population the primary beneficiaries. ${ }^{81}$ Further, over time it has come to be widely recognised that human rights law, too, is binding on an occupying power..$^{82}$ Hence, in an occupation situation there are three recognised paradigmatic concerns: the sovereign authority of the ousted government, the protection of the civilians of the territory and the human rights of each individual. The law on NSGTs is not so different: the 'well-being of the inhabitants' is paramount, ${ }^{83}$ and of course human rights for individuals apply universally today. ${ }^{84}$ There is no ousted sovereign for an NSGT, but instead there is the political right of self-determination of the people..$^{85}$

As noted, the UN Legal Counsel and the three European courts demanded that the people of Western Sahara not only be well-treated but also consulted, ${ }^{86}$ thus adding a fourth concern to the three of the law of occupation - the self-determination of the people as a collective unit. ${ }^{87}$ This concern is central to the law on NSGTs, of course. Is

\footnotetext{
Humanitarian Law Violations by Private Actors in Occupied Territories and the Exploitation of Natural Resources' (2016) 63 Netherlands International Law Review 251, 255-56. For a full discussion of the relation between the law of occuppation and trusteeship, see Ralph Wilde, 'From Trusteeship to Self-Determination and Back again: The Role of the Hague Regulations in the Evolution of International Trusteeship, and the Framework of Rights and Duties of Occupying Powers' (2009) 31 Loyolaof Los Angeles International and Comparative Law Review 85.

${ }^{81}$ See Arai-Takahashi (n 5) 68.

${ }^{82}$ Of course, this is not without exception. The US and Israel are two prominent dissidents.

${ }^{83}$ Charter of the United Nations and Statue of the International Court of Justice (entered into force 24 October 1945) 1 UNTS 16, Article 73.

${ }^{84}$ As for the human rights treaties, their territorial scope of application may be limited, but the presumption is that they are not. Sarah Joseph and Melissa Castan, The International Covenant on Civil and Political Rights: Cases, Materials, and Commentary (3rd edn, Oxford University Press 2013) 93.

However, customary human rights apply universally.

$85 \mathrm{cf}$ the discussion in $\mathrm{n} 99$.

${ }^{86}$ The High Court, the General Court and the Legal Counsel said so explicitly, while the Court of Justice found that the agreements did not cover Western Sahara because the people had not consented to that. Polisario 2016 (n 4) para 106.

${ }^{87}$ For sure, one can categorise self-determination as a human right, and its placement in the 1966 Covenants certainly suggests that. However, it has not been conceptualised as an individual right, so
} 
it a feature also of the law of occupation?

Self-determination has an external aspect - the right to determine the political future of the territory - and an internal one - the right to participate in governance. ${ }^{88}$ The external aspect supports the 'conservationist' tendency in occupation law. The internal aspect could be used to justify violations of the conservationist principle - as was suggested regarding the constitutional changes made in Iraq - but one could also relate it to the management of the occupied territory. In The Wall Opinion, the ICJ held that the construction of the wall (or barrier), 'along with measures taken previously ... severely impedes the exercise by the Palestinian people of its right to self-determination' ${ }^{89}$ This passage is obscure, but it seems to me that it related not just to the final status of the occupied Palestinian territories (the external aspect) but also to the day-to-day management of the affairs of the Palestinian people - the internal aspect of self-determination..$^{90}$

The ICJ linked the right of self-determination to the concept of a sacred trust as a limitation of the authority of an administrator. ${ }^{91}$ That concept is taken from Article 22 of the League Covenant as well as from the chapeau of Article 73 of the UN Charter, which speaks of a 'sacred trust' 'to promote to the utmost... the well-being of the inhabitants' of the NSGT. In the Namibia opinion, the ICJ used this term in relation to the South African administration of the former mandate of South-West Africa, which

\footnotetext{
the difference is relevant.

${ }^{88}$ Some scholars have translated this into an entitlement to democracy. See Gregory H. Fox and Brad R. Roth (eds), Democratic governance and international law (Cambridge University Press 2000) and in particular Thomas M. Franck's seminal 'Legitimacy and the Democratic Entitlement', reproduced in ibid 25-47; Antonio Cassese, Self-Determination of Peoples: A Legal Reappraisal (Cambridge University Press 1995) 53, 310 and passim. See also Hurst Hannum, 'Rethinking Self-Determination' (1993) 34 Virginia Journal of International Law 1, 34 and passim.

${ }^{89}$ See Wall (n 37) [122 cf with 118]. See also Daniel Thürer and Thomas Burri, 'Self-Determination', Max Planck Encyclopedia of Public International Law', December 2008, para 34.

${ }^{90}$ Hence, I am not sure that the interpretation given by Judge Higgins in her separate opinion is the most plausible one. Legal Consequences of the Construction of a Wall in the Occupied Palestinian Territory, Advisory Opinion [2004] ICJ Rep 136, separate opinion of Judge Higgins, [30].

${ }^{91}$ Wall (n 37) [88].
} 
South Africa 'occupied' 'illegally'. ${ }^{92}$ Gros comments that ' $[t]$ he Court thus seems to be constructing a "sacred trust" concept ... as the common denominator of all situations where people are not self-governing, including occupation. ${ }^{\prime 93}$ This is echoed by Benvenisti who says that 'the occupant's status is conceived to be that of a trustee' and that 'contemporary attention is paid more to the indigenous community under occupation rather than to the wishes of the ousted government.' 94 Hence, both an occupant and an adminstering power can be thought of as trustees on behalf of a community. Indeed, while it used to be the idea that for occupied sovereign territory, it is the ousted sovereign that retains sovereignty, a more modern expression is to say that '[i]n light of the principle of self-determination, sovereignty and title in an occupied territory $\ldots$ remain with the population under occupation' ${ }^{95}$ Thus, the concept of 'trustee', a key-term in the law on NSGTs, is now established in discourse on occupation. ${ }^{96}$ Perhaps the idea that the people should be consulted has travelled the same route: Benvenisti finds that 'the emerging expectation that states offer effective opportunities for participation of individuals in shaping public

\footnotetext{
92 The Court went on to state that ' $\mathrm{t}$ ] hese developments leave little doubt that the ultimate objective of the sacred trust' referred to in Covenant of the League of Nations, Article 22, para 1, 'was the selfdetermination ... of the peoples concerned'. Namibia Opinion (n 48) [53]. The Court used the word 'occupation' to characterise the South African presence, in paras 118 and 119 as well as in the dispositif. See also Wall (n 37) [172].

${ }^{93}$ Aeyal Gross, The Writing on the Wall: Rethinking the International Law of Occupation, (Cambridge

University Press 2017) 28, 165.

${ }^{94}$ Benvenisti (n 5) 6-7.

${ }^{95}$ Crawford opinion (n 41) 12. See also: '[S]overeignty is vested in the population under occupation' Gross (n 93) 18; Arai-Takahashi (n 5) 68.

${ }^{96}$ On the concept of trusteeship in these two contexts, see Wilde (n 80).

The genealogy of the use of the word 'trust' in occupation discourse would be an interesting project in itself. While it was a crucial concept from the start in the law on NSGTs, it seems to have seeped in to the law on occupation gradually. Dinstein opposes the use of the concept, (Dinstein (n 38) 36), but it is used by Roberts (Adam Roberts, 'What is a Military Occupation?'(1985) 55 British Yearbook of International Law 249, 259. One of the earliest uses is no doubt that of Arnold Wilson, who even used the term 'sacred trust', though in the context of the occupation of Iraq after the First World War, which preceded the creation of the mandate of Iraq under the League of Nations regime. Arnold Wilson, 'The Laws of War in Occupied Territory'(1932) 18 Transactions of the Grotius Society 17, 29. Note that there is a difference between being a trustee of public property, as provided for in Article 55 of the Hague IV Regulations (n 7), and being a trustee of the political and legal order, as provided for in, for instance, Article 43, and that usages of the word trustee in the context of occupation may not necessarily cover both aspects.
} 
policies' should 'arguably' 'inform the interpretation of Article 43' of the Hague Regulations (Hague IV), ${ }^{97}$ and an ICRC expert meeting held that 'long-term occupation required the occupying power to take into consideration the will of the local population'.$^{98}$ One might conclude that until a people can (again) exercise their right to external self-determination, the power in force has to let them exercise internal self-determination by taking part in the governance of the territory. If that is correct, the legal situation appears rather harmonious: two bodies of law (occupation and self-determination) may apply, and they now both exhort the controlling power to take the will of people into account. ${ }^{99}$

\section{3 What is the basis of each regime?}

So, it appears that the two regimes to a significant degree coincide or at least interact congenially, and three legal institutions (the High Court, the General Court, the UN Legal Counsel) did not find it necessary to sort out the relation between them. What is even more interesting is that none of the three bothered to make a substantive distinction based on whether the (de facto) authority of Morocco had been

\footnotetext{
${ }^{97}$ Benvenisti (n 5) 79-80. Cassese wrote in 1992 that the notion of an permanent sovereignty over natural resources 'tends to support a restrictive interpretation of the occupant's powers to exploit and dispose of immovable property.' Antonio Cassese, 'Powers and Duties of an Occupant in relation to Land and natural Resources' in Emma Playfair (ed), International Law and the Administration of Occupied Territories (Clarendon Press 1992) 419, 426.

${ }^{98}$ Expert Meeting (n 47) 75-76. For a different but slightly ambigous view, see Malcolm Shaw, 'Terrirorial administration by Non-territorial Sovereigns' in Tomer Broude and Yuval Shany (eds), The Shifting Allocation of Authority in International Law: Considering Sovereignty, Supremacy and Subsidiarity (Bloomsbury Publishing 2008) 369, 409. It should also be noted that the US Military Manual does not mention any obligations to consult the population of the occupied territory. US Department of Defence, Law of War Manual (2015) $735 \mathrm{ff}$.

${ }^{99}$ One may ask whether the existence of an intact ousted government would mean that there would be no reason to consult the people. Are consultations with an occupied people just a substitute, when there is no government to consult, or do such consultations have an independent value even if there is a ousted government? In those situations that have prompted most of the recent discussion on occupation - Iraq and the Middle East - there has been no ousted authority that can credibly be consulted. In cases like occupied Kuwait (1990-1991), the government would be a legitimate representative, while the situation is more complex in Northern Cyprus and Crimea, where large parts of the population sympathise with the occupiers and feel that they had grievances against the previously effective government (which is not at all to legitimise the interventions in 1974 and 2014, respectively).
} 
established in accordance with or in violation of international law.

This brings me to the question of the bases for each regime, the trigger, if you will. Different rules apply in different situations and each rule is - directly or indirectly -connected to a rule of application, a rule which refers to a certain 'fact'. If a certain set of facts are at hand, a certain set of rules are to be applied by a certain authority. I will call this factual basis.

However, my question goes further: What is it that justifies that one fact rather than another one is the precondition for an authority's application of a regime to an individual? Why should we provide an occupying or an administrative power with a certain authority? I will call this the political basis.

Even though Morocco's authority is severely circumscribed, it may, nevertheless use the resources of that territory, under certain conditions. This right seems to be based on 'a fact' (the General Court) or 'de facto control' (the High Court) or 'de facto administered' (Corell). ${ }^{100}$ How does this relate to the bases for the application of the law of occupation or the law relating to NSGTs?

Article 43 of the Hague Regulations speaks of '[t]he authority ... having in fact passed into the hands of the occupant', and it is generally held that the powers of an occupant arise out of a 'fact', namely effective control ${ }^{101}$ or, in Dinstein's words, 'the power of the bayonet'. ${ }^{102}$ Oppenheim famously said that the authority is 'not by right' $^{\prime 103}$ but 'the martial law of the occupying power ipso facto' ${ }^{104}$

It is more difficult to find a generally agreed factual basis for the authority of

\footnotetext{
100 Corell (n 57) 238.

101 Benvenisti (n 5) 43.

102 Dinstein (n 38) 35.

${ }^{103}$ Oppenheim (n 5) 364. See further Michael Bothe's report to the ICRC expert meeting, '[t]he power exercised by the occupant is its own original power limited by international law; it is not a power delegated or derived from the State whose territory is occupied'. Michael Bothe, "'Effective Control": A Situation Triggering the Application of the Law of Belligerent Occupation', Expert Meeting (n 47) 36. cf also Bhuta (n 5) 727.

104 Oppenheim (n 5) 368.
} 
'administering powers' of NSGTs (colonial powers). While the colonial states have invoked intertemporal law and claimed that their takings were legal at the time and that their remaining titles are still good, ${ }^{105}$ many third world states have attacked and tried to delegitimise colonial claims to sovereignty. ${ }^{106}$ Perhaps administration of a non-self-governing territory can most plausibly be based on control as a fact, too. Effective control is the most important basis for title to territory, including 'terra nullius', ${ }^{107}$ and continued occupation is necessary in order to not lose such title. However, in distinction to 'full' sovereignty, the authority of an administering power of a non-self-governing territory is now limited, as recounted in section 2.2. If so, not only has the substance of the two regimes converged, so has the political basis, meaning that the (limited) right to administer (temporarily) flows out of the fact of control. ${ }^{108}$

Does this also apply to control that is the result of a manifest violation of international law? One could certainly argue that even the quite limited rights of an occupying power shall be denied to an aggressor, ${ }^{109}$ that is, an alleged 'illegal'

105 See James Crawford, The Creation of States in International Law (Oxford University Press 2006) 61315. See also Arai-Takahashi (n 5) 74-77.

106 Inis Claude, 'Collective Legitimization as a Political Function of the United Nations' (1966) 20 International Organization 367, 376-77. See also Sundhya Pahuja, Decolonising International Law: Development, Economic Growth and the Politics of Universality (Cambridge University Press 2011) 81-82. ${ }^{107}$ Seokwoo Lee, 'Continuing Relevance of Traditional Modes of Territorial Acquisition in International Law and a Modest Proposal'(2000) 16 Connecticut Journal of International Law 1. Of the four traditional modes of acquisition of territory, only cession does not necessarily involve effective control. However, if a rare case would occur in which the ceded territory would not be effectively taken over by the recipient state, the lack of control would surely be an important aspect. For the history of colonial acquisitions, see Antony Anghie, Imperialism, Sovereignty and the Making of International Law (Cambridge University Press 2007) $82 \mathrm{ff}$ and Martti Koskenniemi, The Gentle Civilizer of Nations: The Rise and Fall of International Law 1870-1960 (Cambridge University Press 2002) 98 ff. ${ }^{108}$ Max Radin made a similar remark regarding the Roman concepts of possession and dominium. See Max Radin, 'Fundamental Concepts of the Roman Law' (1925) 13 California Law Review 207, 218-19. ${ }^{109}$ Talmon suggests that '[s]tates may, for example, refuse to recognize and enforce laws enacted by the aggressor for the occupied territory or may deny recognition to title to property even if the acquisition of property was within the 1907 Hague Regulations on Land Warfare.' Talmon (n 46) 117. See also the discussion in Yaël Ronen, 'Illegal Occupation and Its Consequences' (2008) 41 Israel Law Review 201. For a general discussion on the relation between the jus ad bellum and the law of occupation, see Rotem Giladi, 'The Jus Ad Bellum/Jus In Bello Distinction and the Law of Occupation' (2008) 41 Israel Law Review 246, 227-241. 
occupier like Morocco should have no right to adminster at all. Yet, the courts did not attach much significance to the origin of the Moroccan control of Western Sahara. Although the General Court and the High Court noted that Morocco was only 'de facto' administering Western Sahara, they still applied the rules applicable to the adminstration of an NSGT. ${ }^{110}$ Hence, the illegal origin of Moroccan control (a use of force, if not an act aggression) meant that it did not have title to sovereignty, but that did not affect the application of the regime of NSGTs. This is well in line with the law of occupation, which - as a part of the jus in bello -- applies regardless of whether the occupant achieved control over the territory in violation of international law or not. ${ }^{111}$ In Benvenisti's words: ${ }^{112}$

The emphasis is thus put not on the course through which the territory came under the foreign state's control ... but rather on the phenomenon of occupation: the exceptional exercise of public power by one state in a foreign territory and over its inhabitants.

This explains why the various legal institutions were not concerned with the origin of Moroccan control. Both the law of occupation and the law on NSGTs apply erga omnes, to whoever is in control.

One reasonable conclusion is that if there is no title, then the basic rule must be that administration should be carried out so as to not prejudice a future settlement regarding the permanent sovereignty over the territory, regardless of whether the situation is one of occupation or of (colonial) administration of an NSGT, and regardless of whether or not the taking of control was legal. If it does not matter

\footnotetext{
110 Even the Advocate General did that, although he refused to assign the designation 'de facto administering authority' to Morocco. See Advocate General, 2018 (n 33) para 232.

111 Shaw (n 98) 409. See also Dinstein (n 38) 3 and Knut Dörmann, 'Foreword' in Expert Meeting (n 47) 4. See also Ronen (n 109) 237.

112 Benvenisti (n 5) 3. This is, of course, in stark contrast with the colonial concept of pacific occupation. See Institut de Droit International, 'Projet de déclaration internationale relative aux occupations de territoires, resolution adopted at the Institute's Session de Lausanne in 1888', http://www.idi-iil.org/app/uploads/2017/06/1888 lau 02 fr.pdf.
} 
whether the act that put the governing state in control was in agreement or not with international law, perhaps that is so because both an occupant's and an adminstering power's authority is now so circumscribed that there appears to be little need for a stricter governing regime for mala fide than for bona fide possessors. ${ }^{113}$

\section{Afterthought: Sovereign, occupied, non-self-governing-- does it matter?}

Occupation and rule over an NSGT are both abnormal forms of authority in a Westphalian system of sovereign states. However, the laws of occupation and NSGT are both dependent on that of sovereignty - they are sovereignty in suspense or sovereignty as a promise. ${ }^{114}$

Philosophers find the political basis for sovereignty in the people -- popular self-rule (Rousseau) or consent (Hobbes, Locke). Still, the legal recognition of concrete instances of sovereignty - new independent states, acquisition of territory - has usually hinged on the same sort of fact as occupation rests on, namely effective control. Crawford finds that even though 'norms that are non-derogable and peremptory cannot be violated by State-creation', the principle of effectiveness '[n]o doubt ... remains a major consideration' ${ }^{115}$ Further, just like the authority of an occupier or an administrator, the exercise of sovereign authority is circumscribed by numerous obligations like human rights law including the right to participate in governance.

Perhaps the differences between various 'forms of territorial rule' are not that great. ${ }^{116}$ Perhaps dealings in natural resources by a sovereign, an administrator or an

\footnotetext{
${ }^{113}$ Of course, this does not change the fact that the manner in which the state got possession might be a violation of the jus contra bellum, and that there therefore is a jus ad bellum obligation to withdraw. $114 \mathrm{cf}$ Benvenisti's characterisation of the concept of occupation as the 'mirror image' of the concept of sovereignty. Benvenisti (n 5) 21.

${ }_{115}$ Crawford (n 105) 107.

${ }_{116}$ Martti Koskenniemi, ‘Occupation and Sovereignty-Still a Useful Distinction?' in Ola Engdahl and Pål Wrange (eds) Law at War: The Law as it Was and the Law as it Should Be (Brill 2008) 163, 171.
} 
occupier are legitimate only if it is for the good of the people and with their consent. Perhaps it is better to think of all of this in terms of different bundles of rights and obligations attached to various forms of governance, each bundle being exercised by one group of people over another group, at every here and now regulated by a particular constellation of international legal regimes. ${ }^{117}$ If so, could not the principles of permanent sovereignty over natural reslurces apply to any exercise of authority over people? If we request about the interests and wishes of the people of Western Sahara, why not ask the people of Morocco how they want to use their natural resources?

However, that is to simplify things too much. As shown by the legal practice at hand, internal self-determination can to some extent be enforced before external selfdetermination has been exercised, ${ }^{118}$ but hardly thereafter. And the same goes for the limitations incumbent upon an occupant. For sure, in principle the right of selfdetermination requires that the people are allowed to 'freely pursue their economic, social and cultural development' ${ }^{\prime 119}$ and there is the human right to 'take part in the conduct of public affairs, directly or through freely chosen representatives'. ${ }^{120}$ And in the recognition of new states, the will of the people in the territory is sometimes taken into account, and sometimes that is the case also in the 'recognition' of governments. But once a state has been established and its government is in place,

\footnotetext{
${ }^{117}$ One could also think of it as a sliding scale of rules, rights and obligations. cf Koskenniemi (n 116) 170. As mentioned, Benvenisti refers to the two concepts of occupation and sovereignty as 'mirrorimages', which is, of course, a metaphor with different connotations. Benvenisti (n 5) 21. cf also Gross: '... it is necessary to shift from a binary approach to the existence of occupation to one that considers that duties follow from the exercise of control, regardless of whether the situation is conceptualised as falling into the category of occupation or of sovereignty.' Gross (n 93) 130. For Gross, this perspective entails that '...the responsibility of an occupier is as great as its power.' Gross (n 93) 133. It should be pointed out that this view - which focuses on the responsibilities rather than the rights of the governing party - is not necessarily incompatible with the non-(or even anti-)functionalist view of the relation between occupation and sovereignty espoused by Koskenniemi, which I also subscribe to (but in a more equivocal way).

118 Cassese, Self Determination (n 88) 73.

119 International Covenant on Civil and Political Rights (entered into force 23 March 1976) 999 UNTS 171 (ICCPR), art 1.

$120 \mathrm{ibid}$, art 25.
} 
no court will declare a treaty or a concession contract invalid because it was not concluded with democratic pedigree. ${ }^{121}$

In fact, one can even argue that an occupied people may be better off than a sovereign one in some respects. In a non-self-governing or occupied territory, the power is accountable under the UN Charter as a trustee and/or under IHL as an occupant, but in a sovereign state, legitimate authority is presumed. ${ }^{122}$ Schrijver finds that apart from Resolution $1803^{123}$ and a few other UN Resolutions

only cursory evidence can be found that under international law States have a duty to exercise their right to permanent sovereignty over natural resources in the interest of national development and to ensure that their inhabitants benefit from resource exploitation ${ }^{124}$

Even less, presumably, would there be evidence of an obligation to consult the people when natural resources are being used. If you think about it this way, the status of independence seems a slightly less attractive goal for a people.

But that is not how leaders of colonised peoples have thought about it. 'We have awakened. We will not sleep anymore', said Nkrumah of Ghana in 1957. ${ }^{125}$ 'We are going to ensure that the lands of our fatherland truly profit to its children,' said Lumumba of the Congo three years later. ${ }^{126}$ Sovereignty entails the possibility to

\footnotetext{
${ }^{121}$ Except in the rare case that the consent to be bound by a treaty was in violation of a domestic law on competence and that violation was 'manifest and concerned a rule of its internal law of fundamental importance'. VCLT (n 67), art 46.

122 cf Koskenniemi (n 116) 164.

${ }^{123}$ UNGA Res 1803(XVII), 14 December 1962, UN Doc A/RES/1803 (1962).

${ }^{124}$ Nico Schrijver, Sovereignty over Natural Resources: Balancing Rights and Duties (Cambridge University Press 1997) 311. Duruigbo, evidently arguing in a de sententia ferenda mode, says that governments should be responsible towards their citizens, being in 'a position of trust in relation to their countries' natural resources'. Emeka Duruigbo, 'Permanent Sovereignty and Peoples' Ownership of Natural Resources in International Law' (2006) 38 George Washington International Law Review 33, 67. See also Okowa (n 80) 246 and 258 (the latter being more of a de sententia ferenda statement, I assume).

${ }^{125}$ Kwame Nkrumah, '"Ghana is Free Forever"', BBC World Service Kwame Nkrumah's speech at independence, 6 March 1957

http://www.bbc.co.uk/worldservice/focusonafrica/news/story/2007/02/070129 ghana50 independence speech.shtml.

126 Thomas Turner, 'Independence Day: Fifty Years after Lumumba Speech, DRC's Riches Still Not
} 
pursue development 'without external interference'. ${ }^{127}$ Upon independence, the inhabitants of a territory become citizens of a sovereign state, a population becomes a polity, an administrator gives way to representatives. Under the regime of sovereignty, the government is presumably 'representing the whole people belonging to the territory without distinction as to race, creed or colour' ${ }^{\prime}{ }^{28}$ There are good principled reasons to be asking the government of Morocco hard questions for the people Western Sahara but give them the benefit of the doubt regarding the people of Morocco. We can pierce the sovereign veil to some extent and demand compliance with human rights, but if we second-guess every decision or prescribe the details for a good system of governance, there is not much left of pluralism. ${ }^{129}$ After all, there is no neutral ground from which to judge - just the one or the other particularist claim that may (or may not) have been elevated to universality.

But, to return to my doubts, that presumption cannot be unrebuttable, ${ }^{130}$ because that group of people that has been given the authority to rule under the principle of sovereignty can abuse their powers. And if they do, they undermine the political basis for our distinction between full sovereignty and other forms of authority. In 1958 Nkrumah introduced the Preventive Detention Act to curb his opposition. In

Benefiting her Children', Carngie Council for Ethics \& International Affairs, 3 June 2010 https://www.carnegiecouncil.org/publications/ethics online/0046/:pf printable.

${ }_{127}$ My emphasis. UNGA Res 2625(XXV) (n 22); Article 1, ICCPR. cf also Hinsley, sovereignty is 'the pre-condition of effective action in and for the community'. F.H. Hinsley, Sovereignty (2nd edn, Cambridge University Press 1968) 223.

${ }^{128}$ The quotation is from the development of the principle of equal rights and self-determination of peoples in the Friendly Relations Declaration, attached to UNGA Res 2625(XXV) (n 22).

${ }^{129} \mathrm{cf}$, in favour of diversity, Hurst Hannum, Autonomy, Sovereignty, and Self-Determination: The Accomodation of Conflicting Rights (University of Pennsylvania Press 1989) 26. Issues like these were discussed in Anne-Marie Slaughter, 'A Liberal Theory of International Law' (2000) 94 American Society of International Law Proceedings 240. See Susan Marks, The Riddle of all Constitutions: International Law, Democracy, and the Critique of Ideology (Oxford University Press 2000) and Fox and Roth (n 88). My own contribution, Pål Wrange, 'Liberalism and the End of International Law?', Stockholm University, Faculty of Law Research Paper No. 18, March 2000.

${ }^{130}$ On odious debt, see Robert Howse, 'The Concept of Odious Debt in Public International Law', UNCTAD Discussion Paper No. 185, July 2007. 
1965, as Congo emerged out of civil war and foreign interventions, Lumumba's former secretary Mobuto took power, depleting the country's resources until 1997, when he was exiled to Morocco and his old friend, Hassan II, who in the meantime had not only occupied Western Sahara but also extracted a fortune from phosphates and other Moroccan and Sahrawi resources. Distinctions of status established by law (sovereign, occupied, non-self-governing etc) may be worthy of protection, but they are nevertheless arbitrary, and whether or not they serve justice cannot be determined in the abstract. 